\title{
SISTEM INFORMASI ADMINISTRASI DATA KEPEGAWAIAN PADA BAGIAN PERSONALIA PT. XYZ
}

\author{
Putri Kurnia Handayani \\ Dosen Fakultas Teknik, Program Studi Sistem Informasi \\ Universitas Muria Kudus \\ Email: kurnia.putri86@gmail.com
}

\begin{abstract}
ABSTRAK
Sistem informasi personalia adalah suatu sistem yang saling berhubungan dan berinteraksi dengan orang bekerja dalam suatu organisasi untuk mencapai tujuan tertentu. Sistem kepegawaian di PT. XYZ sebagian sudah menggunakan komputer tetapi masih bersifat stand alone, sehingga pemakaian data secara bersamaan tidak dapat dilakukan. Diperlukan sebuah sistem yang dapat membantu masalah ini yaitu sebuah sistem informasi administrasi kepegawaian yang bersifat client server, sehingga penggunaan data secara bersamaan dapat dilakukan. Perancangan sistem menggunakan oriented modelling language (OMT), sedangkan untuk perancangan basis data menggunakan entity relationship diagram (ERD). Berdasarkan perancangan yang telah dilakukan berhasil dibuat sebuah sistem informasi administrasi kepegawaian berorientasi objek di Personalia PT. XYZ yang dapat menampung semua data yang menjadi tugas bagian personalia. Selain itu kemungkinan duplikasi data dapat diatasi dan juga membantu mempercepat kegiatan yang ada pada Personalia.
\end{abstract}

Kata kunci: sistem informasi personalia, OMT.

\section{ABSTRACT}

Personnel information system is a system of interconnected and interacting with people working in an organization to achieve certain goals. Staffing system in PT. XYZ some already use a computer but still stand alone, so the use of data simultaneously can not be done. Required a system that could help this problem is an information system of personnel administration that is client server, so the use of data can simultaneously be carried out. Designing the system using oriented modeling language (OMT), while for the database design using the entity relationship diagram (ERD). Based on the design has been done successfully created a system of personnel administration object-oriented information in Personnel PT. XYZ is able to hold all the data from the tasks of the personnel. Besides the possibility of data duplication can be overcome and also help speed up existing activities in Personnel.

Keywords: personnel information system, OMT.

\section{PENDAHULUAN}

Pengolahan data yang dilakukan dengan baik dan benar akan menghasilkan informasi yang baik dan bermanfaat bagi penggunanya. Pengolahan data yang baik ini tentunya harus diimbangi dengan pengelolaan data yang baik pula. Jangan sampai data yang telah diolah dengan baik ternyata tidak memberikan kemudahan dan manfaat bagi pengguna.

Pemanfaatan sistem informasi elektronik dapat membantu suatu instansi/perusahaan untuk memudahkan pengguna dalam melakukan pengelolaan data sehingga kegiatan administrasinya dapat berjalan dengan lebih produktif, transparan, tertib, tepat, mudah, akurat, terpadu, aman dan efisien. Hal ini sejalan dengan pergeseran paradigma dari regulasi menghambat (wall regulations) menuju regulasi mendorong (enabling regulation).

Sistem informasi administrasi data kepegawaian yang berjalan pada bagian personalia PT. XYZ saat ini masih dilakukan secara manual. Walaupun sebagian sudah ada yang dilakukan secara komputerisasi tetapi masih bersifat stand alone sehingga pemakaian data secara bersamaan pada masing-masing unit tidak dapat dilakukan. Hal ini tentunya akan mengakibatkan lambatnya proses yang berjalan di bagian personalia. Padahal bagian personalia menangani data pegawai yang jumlahnya cukup banyak. Administrasi data kepegawaian di sini meliputi data pegawai, absensi, mutasi karyawan, laporan kesehatan, training dan surat peringatan.

Personalia mendukung area lain dengan membantu mendapatkan personil baru. Dapat disimpulkan bahwa personalia merupakan salah satu sumber daya fisik yang mengalir melalui perusahaan dan departemen sumber daya, mempersiapkan personil untuk melakukan tugasnya dan menangani semua pencatatan yang berhubungan dengan pegawai baru dan lama.

Sistem informasi personalia adalah suatu sistem yang saling berhubungan dan berinteraksi dengan orang bekerja dalam suatu organisasi untuk mencapai tujuan tertentu. Selain itu sistem informasi 
personalia dapat didefinisikan sebagai sistem untuk mengumpulkan dan memelihara data yang menjelaskan sumber daya manusia, mengubah data menjadi informasi dan melaporkan informasi itu kepada pemakai.

Object Oriented Development (OOD) adalah suatu cara pengembangan perangkat lunak dan sistem informasi berdasarkan abstraksi objek-objek. OOD yang digunakan adalah OMT (Oriented Modelling Technique). OMT merupakan metode pengembangan perangkat lunak (atau sistem informasi) dengan metode grafis yang relatif mudah dipahami [1].

\section{METODOLOGI PENELITIAN}

\subsection{Tahapan Penelitian}

Tahapan yang dilakukan dalam penelitian ini adalah pengumpulan data, perencanaan sistem, analisis sistem, perancangan sistem, pengembangan sistem dan implementasi sistem.

a. Pengumpulan data

Data dalam penelitian ini diperoleh melalui observasi, wawancara dan studi kelayakan di bagian personalia. Studi kelayakan yang dilakukan meliputi aspek organisasi, ekonomi dan teknologi. Selain itu juga berdasarkan studi kepustakaan melalui buku yang relevan dengan tema penelitian.

b. Perencanaan sistem

Kegiatan yang dilakukan pada tahap perencanaan adalah identifikasi permasalahan yang ada di bagian personalia. Setelah itu diberikan alternatif solusi yang diusulkan kemudian menentukan prioritas pemecahan masalah yang ada dan terakhir merekomendasikan sistem informasi administrasi kepegawaian berorientasi objek sebagai solusi untuk memecahkan masalah yang ada.

c. Analisis sistem

Menganalisis sistem yang sudah ada dan mencari teori pendukung yang berhubungan dengan proses administrasi kepegawaian.

d. Perancangan sistem

Menyusun gambaran sistem yang akan dibuat meliputi paparan sistem, menentukan kelas-kelas dari paparan sistem untuk kemudian dibuat class diagram dan merencanakan konfigurasi sistem.

e. Implementasi sistem

Kegiatan yang dilakukan adalah mempersiapkan semua kegiatan untuk menerapkan aplikasi yang telah dihasilkan meliputi merancang basis data, menerapkan kelas ke dalam struktur program dan menguji aplikasi yang dihasilkan.

\subsection{Penelitian Terdahulu}

Penelitian yang telah dipublikasikan dalam jurnal berkaitan dengan sistem informasi kepegawaian diantaranya sebagai berikut:

a. Pembangunan Sistem Informasi Data Kepegawaian pada Dinas Koperasi Perindustrian dan Perdagangan Kabupaten Pacitan yang diteliti oleh Keyko Riskian Perdana, dkk menghasilkan sebuah sistem informasi kepegawaian yang pengelolaannya dilakukan secara komputerisasi. Penelitian ini menggunakan bahasa pemrograman PHP dan perancangan menggunakan DFD [2].

b. Sistem Informasi Kepegawaian dan Gaji Madrasah Tsanawiyah Negeri (MTSN) 2 Simo Kab Boyolali oleh Shalihin Miftah, dkk menghasilkan sebuah sistem informasi kepegawaian dan penggajian. Sistem dibuat dengan menggunakan bahasa pemgrograman Microsoft Visual Basic 6.0, perancangan menggunakan UML dan database menggunakan Microsoft Access [3].

c. Rancang Bangun Sistem Informasi Kepegawaian (Studi Kasus PKIS SEKAR TANJUNG Pasuruan) diteliti oleh Rokhmad Fadhlul Wafi, dkk menghasilkan sebuah sistem informasi kepegawaian yang mampu memanajemen pegawai yang berjumlah 604 pegawai. Perancangan sistem menggunakan UML [4].

\section{HASIL DAN PEMBAHASAN}

\subsection{Bagan Alir Sistem Baru yang Diusulkan}

Sistem informasi adalah suatu sistem di dalam suatu organisasi yang mempertemukan kebutuhan pengolahan transaksi harian yang mendukung fungsi operasi organisasi yang bersifat manajerial dengan kegiatan strategi dari suatu organisasi untuk menyediakan kepada pihak luar tertentu dengan laporan-laporan yang diperlukan. Gambaran sistem baru yang diusulkan dibuat dalam bentuk flowchart (gambar 1). Flowchart atau bagan alir adalah bagan (chart) yang menunjukkan alir (flow) di dalam program atau prosedur sistem secara logika. Bagan alir (flowchart) digunakan terutama untuk alat bantu komunikasi dan untuk dokumentasi.Sistem yang diusulkan dibuat sesuai kebutuhan di lapangan tanpa mengurangi fungsi dan tujuan sistem yang berjalan saat ini. 


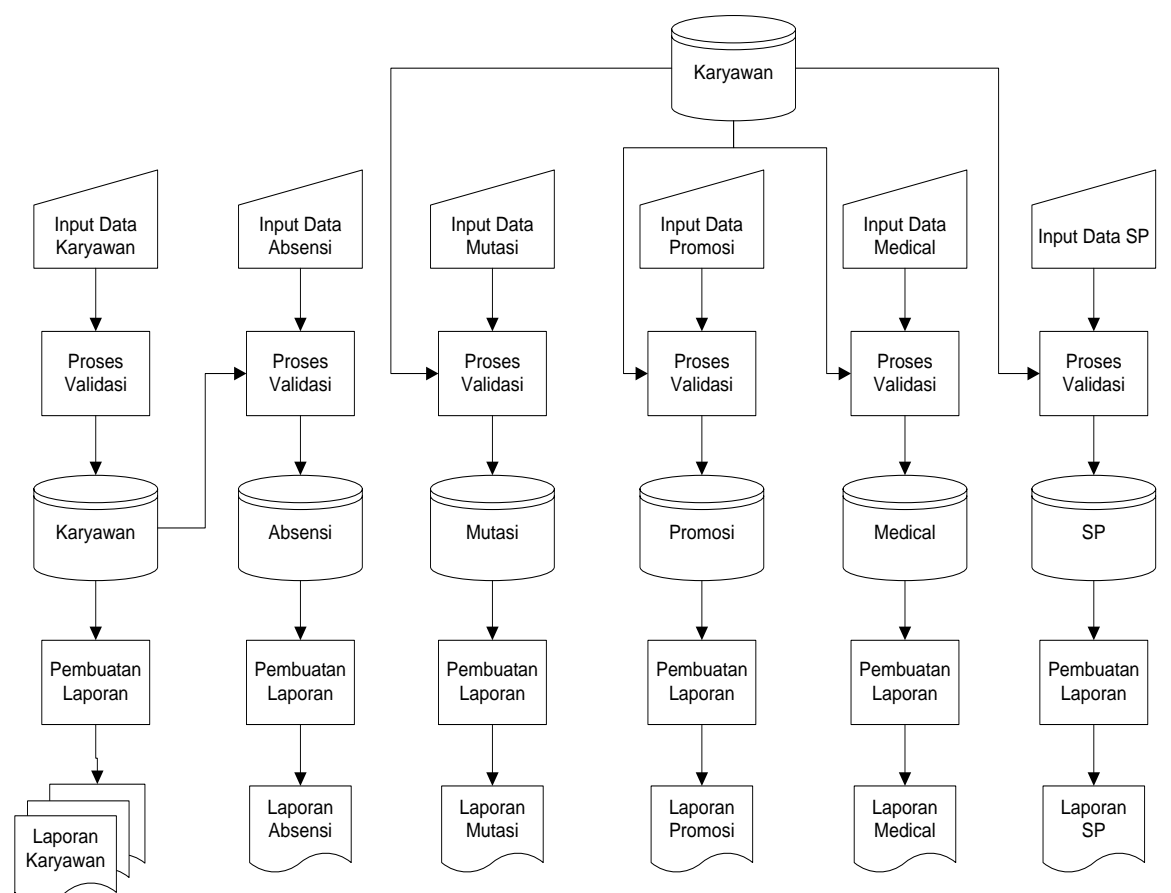

Gambar 1. Flowchart sistem yang diusulkan

\subsection{Class Diagram Sistem Baru}

Kelas didefinisikan sebagai kumpulan/himpunan objek dengan atribut/properti yang mirip, perilaku (operasi) yang mirip, serta hubungan dengan objek lain dengan cara yang mirip (5). Class diagram menggambarkan hubungan antar kelas di dalam sebuah sistem. Berikut adalah class diagram untuk mutasi karyawan (gambar 2).

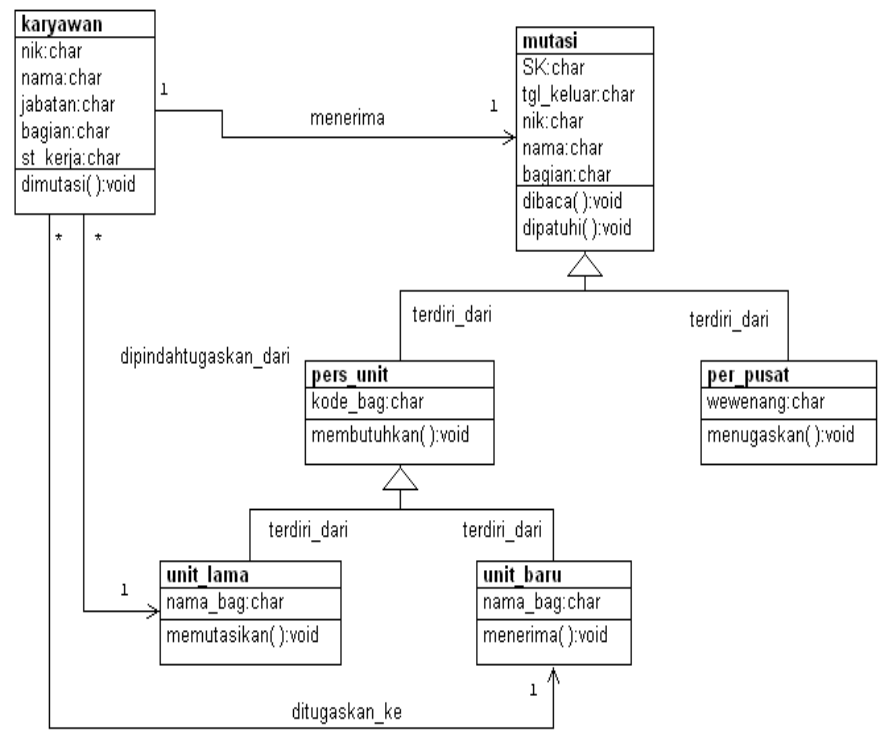

Gambar 2. Class diagram mutasi karyawan

\subsection{Use Case Diagram}

Use Case diagram menggambarkan secara grafis perilaku software aplikasi. Digram tersebut memberikan gambaran mengenai software aplikasi menurut perspektif user dari software aplikasi tersebut (5). Alur sistem untuk mutasi karyawan (gambar 3) dimulai dari personalia unit mengusulkan mutasi karyawan ke personalia pusat. Kemudian personalia pusat memeriksa kondisi di lapangan. Apabila memang mutasi tersebut diperlukan dan sesuai maka dilakukan proses seleksi karyawan yang diusulkan mutasi. Apabila lolos maka dikeluarkan SK mutasi oleh personalia pusat, kemudian diserahkan ke personalia unit untuk selanjutnya diserahkan kepada karyawan yang dimutasi. 


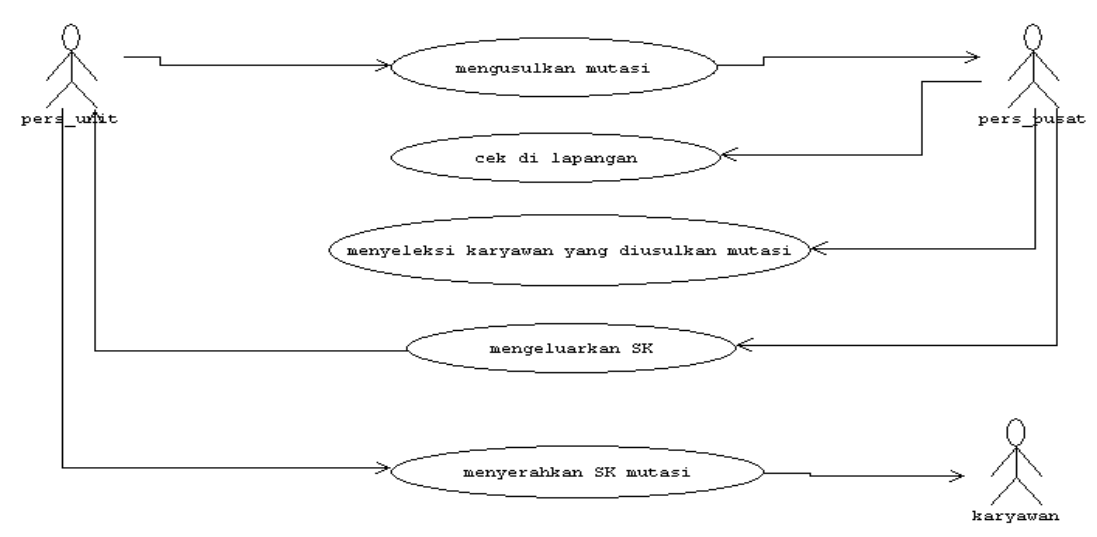

Gambar 3. Use case diagram mutasi karyawan

\subsection{Diagram State}

Diagram state menghubungkan event-event dan state-state. Event adalah sesuatu yang terjadi pada waktu yang terbatas. Event tidak memiliki durasi. Sedangkan state adalah abstraksi dari nilai atribut dan link dalam sebuah objek (5).

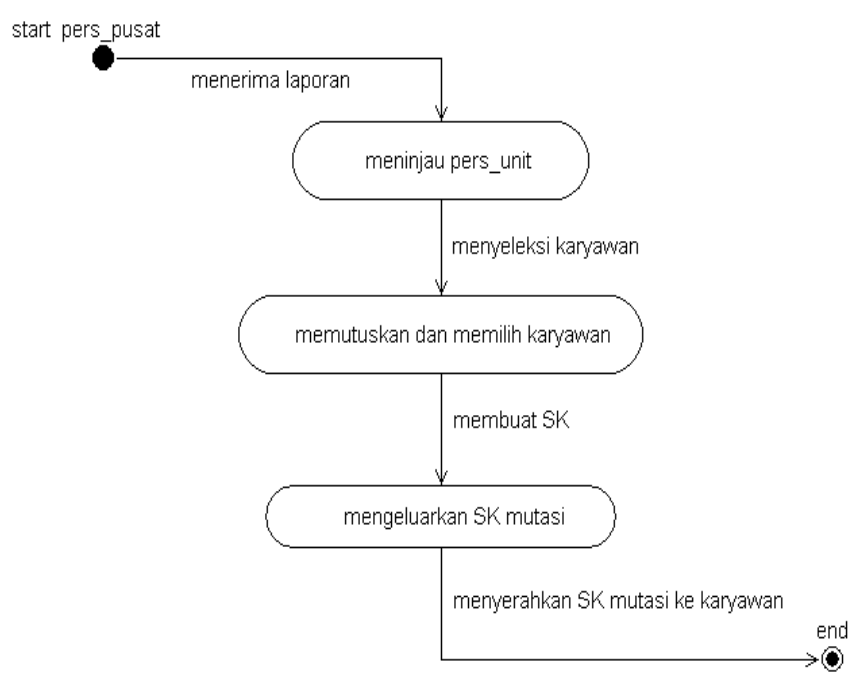

\section{Gambar 4. Diagram state mutasi karyawan}

Diagram state mutasi karyawan dimulai dari personalia pusat menerima laporan usulan mutasi karyawan dari personalia unit, kemudian personalia pusat meninjau lapangan untuk kemudian dilakukan seleksi karyawan. Berdasarkan hasil seleksi dapat diketahui karyawan layak mutasi atau tidak. Jika layak maka dikeluarkan SK mutasi dan diserahkan kepada karyawan (gambar 4).

\subsection{Sequece Diagram}

Sequence diagram atau diagram rangkaian atau satu set diagram rangkaian, langkah-langkah grafik untuk melengkapi kasus yang lebih spesifik termasuk "berbagai alternatif lain atau cara" dengan tanpa menggunakan kasus (5). Diagram lengkap untuk mutasi karyawan dapat dilihat pada (gambar 5).

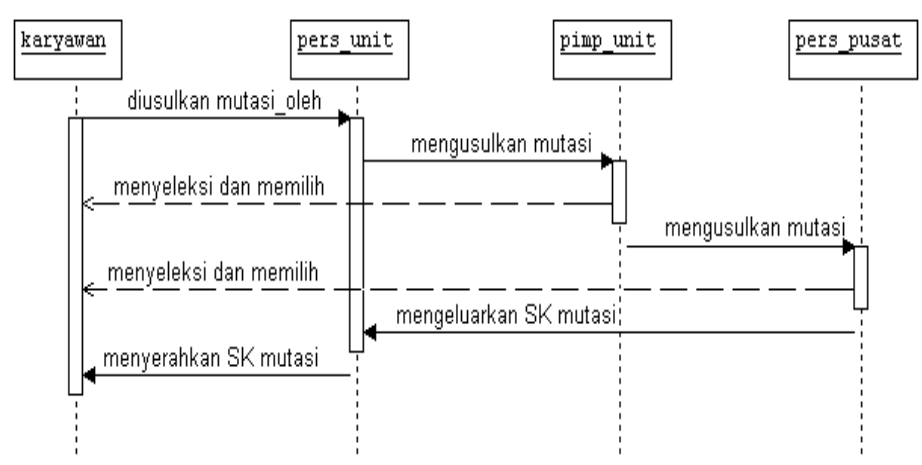

Gambar 5. Sequence diagram mutasi karyawan 


\section{$3.6 \quad E R D$}

Diagram hubungan entitas pada dasarnya adalah diagram yang memperlihatkan entitas-entitas yang terlibat dalam suatu sistem serta hubungan-hubungan (relasi) antar entitas tersebut. ERD yang dihasilkan terdiri dari 5 entitas dan 4 relasi. Masing-masing entitas memiliki atribut dan primary key (gambar 6).

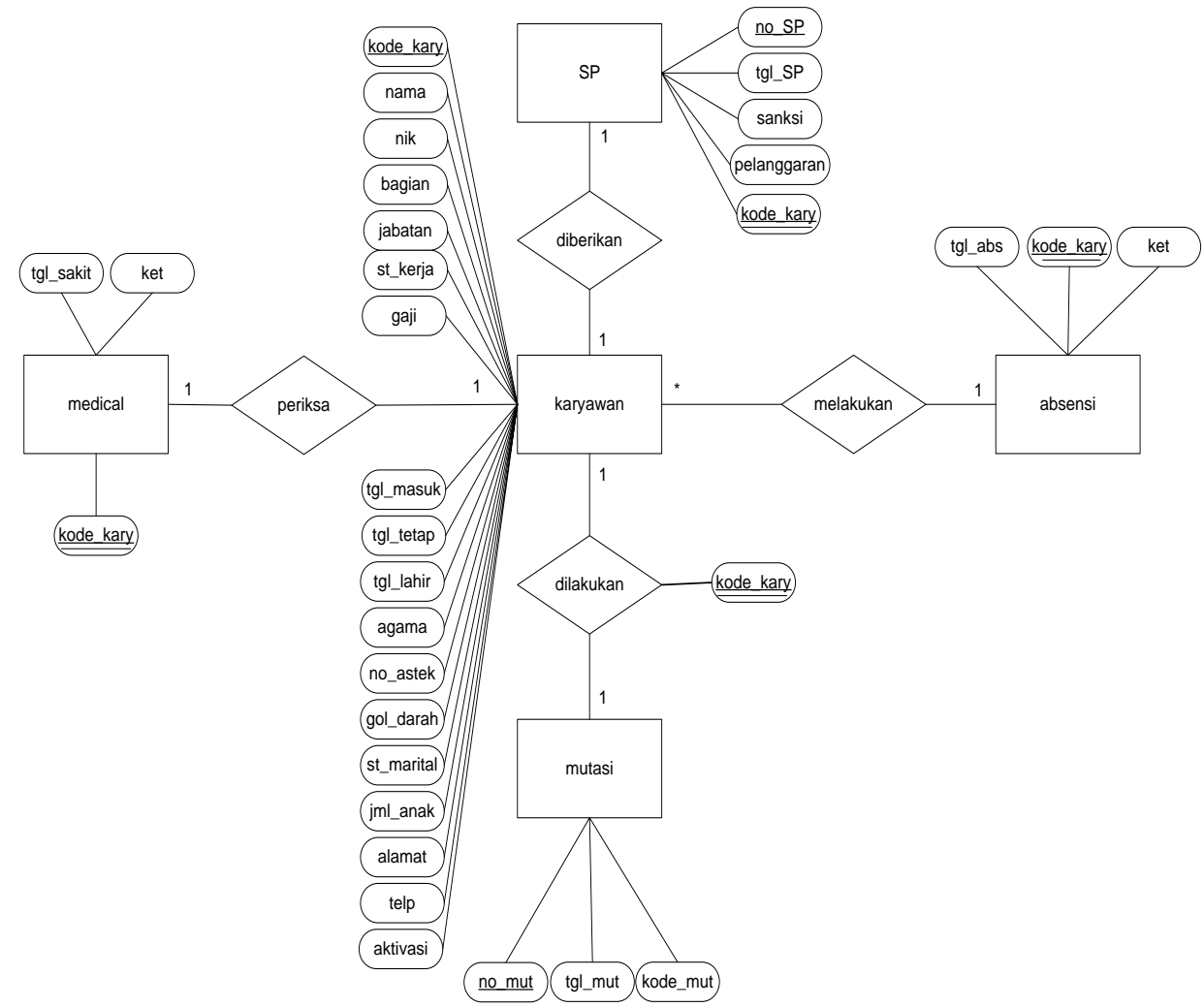

Gambar 6. Entity relationship diagram

\subsection{Form Hasil Perancangan}

Sistem informasi administrasi kepegawaian terdiri dari menu master, transaksi dan laporan. Tampilan awal menu utama (gambar 7). Data master meliputi data karyawan (gambar 8), absensi dan medical. Transaksi meliputi form mutasi, form promosi dan form surat peringatan (gambar 9).

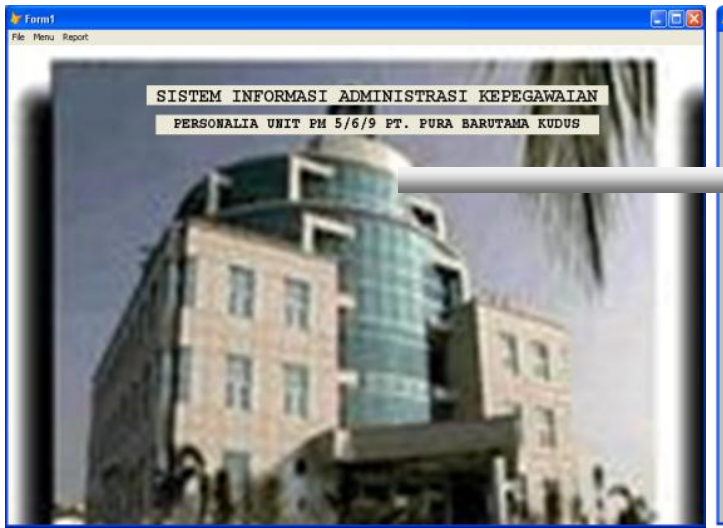

Gambar 7. Menu utama

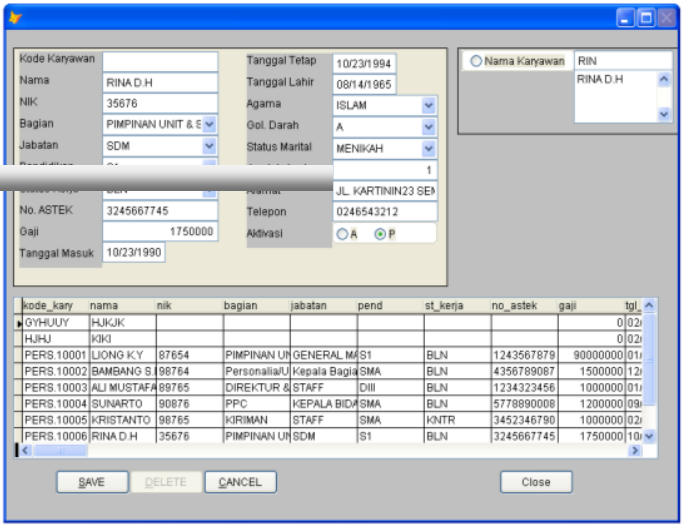

Gambar 8. Form data karyawan

Pada form karyawan ini disediakan fasilitas pencarian nama karyawan untuk memudahkan pencarian data karyawan. Jika diketikkan huruf pada text nama, maka pada list akan muncul nama yang mengandung huruf yang diketikkan pada text nama. Kemudian data muncul pada form inputan. Jika 
ternyata tidak ada nama yang mengandung unsur huruf tersebut, maka muncul pesan "Data tidak ditemukan".

Jika ingin menginput data karyawan baru, maka kita mengisi kode karyawan. Jika ternyata kode karyawan yang diisikan telah ada maka akan muncul pesan "Data sudah ada", kemudian data muncul pada form. Jika ingin mengubah data yang telah ada, maka tinggal mengubahnya kemudian diklik tombol save. Jika ingin menghapus data yang telah ada klik tombol delete. Jika kode karyawan belum ada, maka setelah kita ketik kode karyawan kursor akan set fokus pada nama. Kemudian kita klik tombol save. Untuk membatalkan perintah kita pilih tombol cancel. Untuk keluar dari form, pilih close. Jadi disini tombol save juga berfungsi sebagai tombol edit.

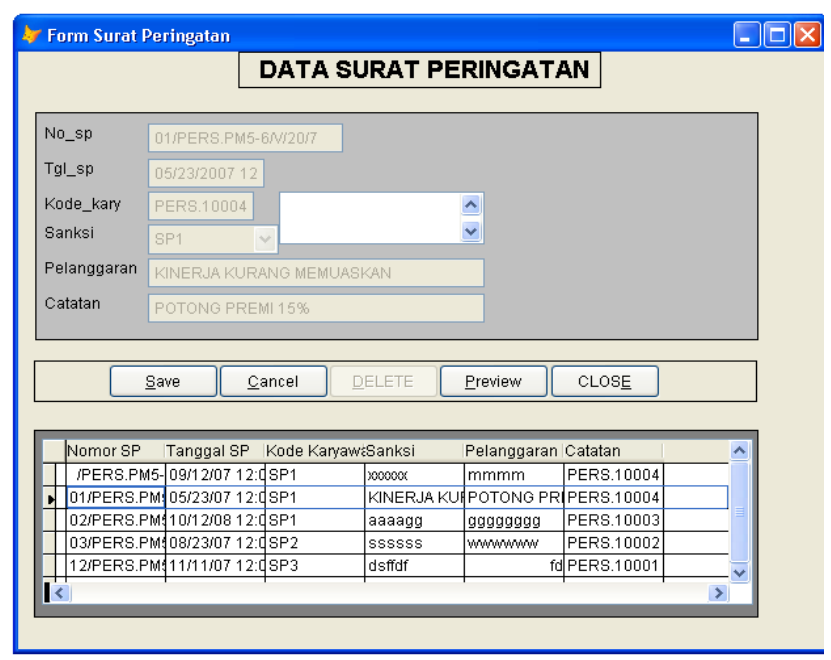

Gambar 9. Form data surat peringatan

Fom surat peringatan digunakan untuk menyimpan data karyawan yang mendapat SP. Setelah data diinput pilih tombol save untuk menyimpan, cancel untuk membatalkan perintah. Untuk edit ketik kode karyawan yang akan diedit kemudian simpan. Atau delete untuk menghapus data. Preview untuk mencetak dan close untuk keluar dari form.

\section{KESIMPULAN}

Berdasarkan perancangan yang telah dilakukan telah berhasil dibuat Sistem Informasi Administrasi Data Kepegawaian pada Bagian Personalia PT. XYZ. Adanya sistem informasi ini diharapkan bagian Personalia mempunyai media penyimpanan/database khusus yang digunakan untuk menampung semua data yang menjadi tugas bagian Personalia/Umum. Selain itu kemungkinan duplikasi data dapat diatasi dan juga membantu mempercepat kegiatan yang ada pada Personalia/Umum sehingga informasi dapat diperoleh dengan cepat, tepat waktu dan akurat. Semakin cepat informasi yang dihasilkan, tentu akan mempercepat pimpinan untuk menentukan suatu keputusan dan tentunya pelayanan terhadap karyawan dapat lebih baik

\section{DAFTAR PUSTAKA}

[1] Nugroho A. Analisis dan Perancangan Sistem Informasi dengan Metodologi Berorientasi Objek Bandung: Informatika; 2002.

[2] Perdana KR, Purnama BE, Iriani S. Pembangunan Sistem Informasi Data Kepegawaian pada Dinas Koperasi Perindustrian dan Perdagangan Kabupaten Pacitan. Indonesian Journal of Network \& Security (IJNS). 2013.

[3] Miftah S, Irianto T, Kusanti J. Sistem Informasi Kepegawaian dan Gaji Madrasah Tsanawiyah Negeri (MTSN) 2 Simo Kab Boyolali. Journal Speed - Sentra Penelitian Engineering dan Edukasi. 2014; 6 .

[4] Wafi RF, Wurijanto T, Soebijono T. Rancang Bangun Sistem Informasi Kepegawaian (Studi Kasus Pkis Sekar Tanjung Pasuruan). JSIKA - Jurnal Sistem Informasi. 2013; 2.

[5] Kristanto A. Perancangan Sistem Informasi dan Aplikasinya Yogyakarta: Gava Media; 2003. 